\title{
THE INTEGRATION OF CHARACTER EDUCATION STRENGTHENING IN THE LEARNING OF LITERATURE APPRECIATION AT SCHOOLS
}

\author{
Achmad Yuhdi \\ Study Program of Indonesian Language and Literature Education, \\ University of Muhammadiyah Sumatera Utara, Medan, Indonesia \\ achmadyuhdi@umsu.ac.id
}

\begin{abstract}
This writing aims to describe the design of learning of literature appreciation at schools by integrating Character Education Strengthening (PPK). The learning of Indonesian literature appreciation as a source of character education does not need to be doubted its existence. Through the revised 2016 edition of 2013 curriculum, the character values strengthening are integrated in the learning process. Some of the characters values are religious, honest, tolerant, disciplined, hard working, creative, independent, democratic, curiosity, nationalism spirit, homeland love, appreciate achievement, communicative, love peace, love reading, environment caring, social caring, and responsible. In the learning of literature appreciation, the character values are interrelated to form values network as a priority of KDP. These five main values of the nation's character are: (1) the religious value, (2) the nationalist value, (3) independence value, (4) of mutual cooperation value, and (5) integrity value.
\end{abstract}

Keywords: Character Education Strengthening, learning of literature, appreciation

Theme: Literature and Linguistics

\section{INTRODUCTION}

Since 2013 until today, the nationally enrolled curriculum in Indonesia is Curriculum 2013. Up to 2017, this curriculum undergoes several stages of change. The important point of the revision made to the curriculum 2013 in 2017 is on improving the relationship or connectivity between Core Competence (KI) and Basic Competence (KD). The next revisions on the arranging of lesson planning by teachers should integrate four things: Character Education Strengthening (PPK), Literacy, 4C (creative, critical thinking, communicative, and collaborative), and HOTS (Higher Order Thinking Skill).

The Character Education Strengthening (hereinafter abbreviated as PPK) is one of the four aspects that need to be strengthened in the curriculum 2013 revised edition of 2017. The PPK according to Presidential Regulation No. 87 year 2017 is an education movement under the responsibility of educational units to strengthen the character of learners through harmonization of heart, taste, thought, and sport with the involvement and cooperation of education, family and community as part of the National Movement for the Mental Revolution (GNRM).

The PPK has aims to: (1) Build and equip students as the Indonesian gold generation in 2045 with pancasila spirit and good education character in order to face the dynamics of future changes; (2) develop a national education platform that places education character as the main spirit in the provision of education for learners with the support of public engagement through formal, non-formal, and informal education with the attention to Indonesian cultural diversity; and (3) revitalize and strengthen the educators' potential and competence, education personnel, learners, community, and the family environment in implementing the PPK.

The implementation of PPK can be conducted on formal, non-formal, and informal education channels. Through formal education, of course, PPK is integrated in intracurricular learning activities. In the intracurricular activities, the character value strengthening is conducted through the activities of strengthening the learning materials and learning methods in accordance with the curriculum content. The characters value here is religious, honest, tolerant, disciplined, hardworking, creative, independent, democratic, curiosity, nationalism spirit, homeland love, appreciating achievement, communicative, 
peace love, read love, environment care, social care, and responsible. (Presidential Regulation No. 87 year 2017).

Before the issuance of Presidential Regulation Number 87 Year 2107, the discussion about character education strengthening has been discussed in the National Education System Act (Sisdiknas) of the Republic of Indonesia Year 20013. According to the law, the character formation is one of the goals of national education. The Article I of National Education Law year 2003 states that the goal of national education is to develop the potential of learners to have intelligence, personality and noble character. The mandate of the National Education Law year 2003 intends that education should not only shape the intelligent Indonesian people, but also the personality or character, so that a generation of developing nations with a character that breathes the noble values of the nation and religion will be born.

Several events that occurred in recent times, such as the death of a teacher by being beaten by one of the students made Indonesia as an emergency state with students' moral. Through Presidential Decree No. 87 year 2017 as described above, the integration of PPK in all subjects needs attention from teachers. As a leader in educating the next generation, the role of teachers is needed to improve the moral degradation of the nation's children today.

The students' character Strengthening is made possible through the literary learning at schools. The goal of literary learning in Indonesian subject is to enjoy and utilize the literary works to broaden the insight, refine the character, and improve the knowledge and language skills. Through the literature appreciation, students can sharpen their feelings, reasoning, imagination, and sensitivity to society, culture, and environment of life. Thus, the lesson planning made by Indonesian language and literature teachers need to integrate the aspects of character education strengthening so that it can be implemented in the process of teaching and learning in the classroom.

\section{DISCUSSION}

\section{Definition of Character Education Strengthening}

Character education is a system of planting the values of character and moral to the citizens of the school which includes the components of knowledge, awareness or willingness, and actions to implement those values, either to God Almighty, personal, among others, environment and nationality in order to become god and useful human. Value always has a positive connotation (Bertens, 2004: 139). The moral value is the highest value. Moral value has characteristics of (1) relating to responsible human personality, (2) relating to the conscience, (3) obliging the human to be absolute inexorably, and (4) being formal (Bertens, 2004: 143-147). Moral value also relates to what should not be done because it relates to the principle of morality to be enforced (Wiramihardja, 2007: 158). It refers also to Soejadi (1999: 21) who interprets values in the sense of good or true with regard to ethical or moral.

Through the curriculum 2013 revised edition of 2016, the character values strengthening is integrated in the learning process. Some of the values of these characters are religious, honest, tolerant, disciplined, hard working, creative, independent, democratic, curiosity, nationalism spirit, homeland love, appreciate achievement, communicative, love peace, love reading, environment caring, social caring, and responsible. The mentioned character values constrict to the five main character values. The five main values of the characters are interrelated to form a value network that needs to be developed as a priority of the PPK movement. The five main values of the nation's character are: (1) the religious value, (2) the nationalist value, (3) independence value, (4) of mutual cooperation value, and (5) integrity value.

The value of the religious character reflects the belief in the one God which is embodied in the behaviour of practicing the religious teachings and beliefs, respecting religion differences, upholding the tolerant attitude towards the practice of religious worship and other faiths, living in harmony and peace with other believers.

The value of this religious character covers three dimensions of the relationship at once, they are the individual relationship with God, the individual with others, and the individual with the universe (environment). The value of this religious character is shown in loving behaviour and maintaining the integrity of creation. Religious values include peaceful love, tolerance, respect for different religions and beliefs, steadfast stance, confidence, interfaith and religious relationships, anti bullies and violence, friendship, sincerity, do not impose the will, love the environment, protect the small and marginalized ones. 
The value of a nationalism character is a way of thinking, acting, and doing that shows loyalty, awareness and high appreciation of the nation's language, the physical, social, cultural, economic, and political environments, placing the interests of the nation and state above the interests of the self and the group. The sub-values of nationalism include the appreciation of the nation's own culture, safeguarding the nation's cultural wealth, willing to sacrifice, excel, and achievement, homeland love, preserve the environment, obey the law, discipline, respect the cultural diversity, ethnicity and religion.

The independent character values are attitudes and behaviours that is independent of others and use all the energy, thought, time to realize hopes, dreams and goals. The sub-values of independence include work ethic (hard work), resilient, professional, creative, courage, and lifelong learners. The value of the mutual cooperation character reflects the act of appreciating the spirit of cooperation and together in solving the common problems, establishing the communication and friendship, providing assistance/help to the people in need. The sub-values of mutual cooperation include appreciation, cooperation, inclusiveness, commitment to joint decisions, consensus deliberation, help, solidarity, empathy, anti-discrimination, nonviolence, and volunteerism.

The value of the integrity character is the value that underlies the behaviour based on the effort to make himself a trustworthy person in words, actions, and work, committed and faithful to humanitarian and moral (moral integrity). The character of integrity includes the attitude of responsibility as a citizen, actively involved in the social life, through the consistency of actions and words based on the truth. The integrity values include honesty, love of truth, faithfulness, moral commitment, anti-corruption, justice, responsibility, exemplary, and respect for the dignity of individuals (especially persons with disabilities).

The five main characters values are not values that stand and develop independently but values that interact with each other, which develop dynamically and form a personal whole. From what places the primary value of any character education begins, the individuals and schools need to develop other key values both contextually and universally. Religious value as a reflection of faith and piety to God Almighty is fully realized in the form of worship in accordance with their own religion and beliefs and in the form of human life as a group, society, and nation. In life as society and nation the religious values are meant to underlie and merge in the main values of nationalism, independence, mutual cooperation, and integrity. And also if the nationalist primary value is used as the starting point for the inculcation of character values, this value should be developed based on the values of faith and piety that grow together with other values.

\section{Integrating the Character Education Strengthening in the Literary Appreciation at Schools}

Besides containing beauty, literature also has a value for the benefit of the reader. The aspect of expediency arises because the creation of literature departs from reality so that a paradigm will be born that good literature re-creates a sense of life. Its creation is conducted together and mutual interwoven as it happens in our own lives. However, the fact is in the literature it is presented through various stages of the creative process. This means that the material of reality is understood through the process of new interpretation by the author. The benefits of literary for the reader, it is concerned with the values that contained in it so that the reader is better able to translate the problems in life through the goodness of the body and the spiritual.

What is meant with the learning of literature appreciation in this discussion is an activity to take the value and meaning of the reading of literary works. The limitation on literary definitions refers to Wellek and Warren's (1980) opinion that divides the literary definitions in three aspects: First, the literary art is everything that is printed. This explanation is not yet complete because it does not include literary works that are not written or spoken. In this case, it is called literature only because of the manuscript as the source. Second, literary arts are limited to well-known books, from the content and form so that the explanations are mixed with judgment. In fact judgment is based on aesthetic aspects only. Third, literature should be limited to imaginative literary art. So this trait shows the world of fantasy and delusion until literature centres on epic, lyrics and drama. The three designated things above are the world of fantasy (fiction).

Abrams (1981) explains the mapping of literary works into four views. First, the literature work as an objective work (something which is autonomous, regardless of any element). Second, the literature work as the work of mimesis (an imitation of the universe). Third, the literature work as a pragmatic work (which gives benefit to the reader). Fourth, the literature works as an expressive work (experiences and thoughts of the creator). Through the above opinion, the literature works have much to 
do with the values in them so that literary connoisseurs are able to interpret the issues of life through social piety and ritual.

As a form to convey the character education in literature to learners, there are some efforts that can be conducted by the teacher. The teacher expresses the values in Indonesian language and literature subject through direct integrating of the character values that are an integral part of the learning subject. Hidayatullah, F (2010: 61) mentions the steps of integrating the character education in the learning subject are as follows: (1) Describing the basic competencies, (2) Identifying the aspects that are integrated into the subjects, (3) Integrating the points (4) Implementing learning, (5) Determining learning method, (6) Determining the evaluation of learning, and (7) Determining the learning resource.

The literature appreciation material by integrating PPK in the curriculum 2013 revised edition of 2017 is presented below in the form of literary teaching materials for high school students of SMA/SMK/equal.

\begin{tabular}{|c|c|c|}
\hline Core Competence & Basic Competence & Character Education \\
\hline \multicolumn{3}{|c|}{ CLASS X } \\
\hline \multirow{5}{*}{$\begin{array}{l}\text { 3. Understanding, applying, } \\
\text { analyzing the factual, } \\
\text { conceptual, and procedural } \\
\text { knowledge based on their } \\
\text { curiosity about science, } \\
\text { technology, art, culture, and } \\
\text { humanities with insight into } \\
\text { humanity, nationality, civics and } \\
\text { civilization relates to the causes } \\
\text { of phenomena and events, and } \\
\text { applying the procedural } \\
\text { knowledge to specific areas of } \\
\text { study according to his or her } \\
\text { talents and interests to solve } \\
\text { problems. }\end{array}$} & $\begin{array}{l}\text { 3.7 Identifying the values and } \\
\text { contents contained in the folklore } \\
\text { (saga) orally and written. }\end{array}$ & $\begin{array}{l}\text { Religious values, nationalism } \\
\text { values, independence values, the } \\
\text { values of mutual cooperation, and } \\
\text { the integrity values }\end{array}$ \\
\hline & $\begin{array}{l}3.8 \text { Comparing the values and } \\
\text { language of folklore and short stories }\end{array}$ & $\begin{array}{l}\text { Religious values, nationalism } \\
\text { values, independence values, the } \\
\text { values of mutual cooperation, and } \\
\text { the integrity values }\end{array}$ \\
\hline & $\begin{array}{l}3.9 \text { Identifying key points from two } \\
\text { non-fictional books (enrichment } \\
\text { books) and one novel that to be read } \\
\text { the values and language of folklore } \\
\text { and short stories. }\end{array}$ & $\begin{array}{l}\text { Religious values, nationalism } \\
\text { values, independence values, the } \\
\text { values of mutual cooperation, and } \\
\text { the integrity values }\end{array}$ \\
\hline & $\begin{array}{l}3.17 \text { Analyzing the elements of poetry } \\
\text { builders }\end{array}$ & $\begin{array}{l}\text { Religious values, nationalism } \\
\text { values, independence values, the } \\
\text { values of mutual cooperation, and } \\
\text { the integrity values }\end{array}$ \\
\hline & $\begin{array}{l}\text { 3.18 Analyzing the contents of at least } \\
\text { one fictional book and one } \\
\text { nonfictional book that has been read }\end{array}$ & $\begin{array}{l}\text { Religious values, nationalism } \\
\text { values, independence values, the } \\
\text { values of mutual cooperation, and } \\
\text { the integrity values }\end{array}$ \\
\hline
\end{tabular}

Table 1 Teaching Material of Literary Appreciation Integrating PPK

Based on the identification of literary materials in the above table, the integration of PPK in literary learning is possible. Literary works that are the source of learning (poetry, prose and drama) contain the discussion that stores the values of these characters. By reading literature, students will meet a variety of people with a variety of problems. Through literature, they are invited to face and experience directly the moral and social categories with all parody and irony.

The space available in literature opens opportunities for the reader to grow up to become a critical person on the one hand, and a wise person on the other. This critical and wise person can be born because the experience of reading a literature has brought them to meet with various themes and backgrounds and various human beings with various characters. Literature in many ways gives readers the opportunity to experience the position of others, which makes it empathetic to the fate and other human situations. Through literature, they can experience being a doctor, teacher, homeless, pedicab driver, cleric, ronggeng, thief, traitor, lawyer, common people, officials, and so on.

The role of teachers in implementing the literature appreciation learning by integrating the PPK starts from making a learning planning. Some activities that teachers can do in integrating the PPK can be detailed as follows: 
a) Preliminary activity

In this activity, teachers can initiate learning with praying activities. This activity is useful to provide strengthening to the students' religious values. Through this activity the teacher can provide guidance to the students that human is a creature that created by God Almighty so that he must obey to His rules.

b) Core activity

The learning of literary appreciation which is conducted on the core activity is the teacher to see the students' understanding after reading the literary works. In the management of the learning process, the teacher should direct the students in the process of reading the literary works. Teachers should direct students to be able to discover the positive values of the literary works they read. They should not free the students to discover and self-conclude the values that exist in the literary work. Furthermore, they guide the students to be able to apply the positive values that have been obtained from literary works in daily life.

\section{c) Closing Activity}

Through this closing activity, teachers can provide the students with an understanding of the expressive benefits of literary works as a medium of character education. They can direct the students to attend some school extracurricular activities for the development of talent in literature. In this activity the students are guided to manage emotions, feelings, opinions, ideas, and views to be internalized in self then poured into the literary work. Emotions, feelings, dissatisfaction with a prevailing system, an angry desire to demonstrate, and the like to something can be actualized in literature, poetry, drama, or prose.

\section{CONCLUSION}

Based on the elements that have been discussed above, it can be concluded that the integration of PPK in learning can be conducted by the teacher at the stage of planning the learning and implementation of learning in the classroom. The character values that are integrated in the two stages of the learning activity of literary appreciation are: (1) religious values, (2) nationalism values, (3) independence values, (4) the value of mutual cooperation, and (5) integrity value. Those Five Character Education Strengthening are implemented gradually and continuously in the literature learning so that it will form the students who have the desired character value of the current learning curriculum.

\section{REFERENCES}

Bertens. 1993.K. Etika.Jakarta: Gramedia Pustaka

Hidayatullah. 2010.Pendidikan Karakter: Membangun Peradaban Bangsa. Surakarta. Yuma Pustaka.

Kanzanuddin. Peran Sastra dalam Pendidikan Karakter.

Soejadi.1999. Pancasila sebagai Sumber Tertib Hukum Indonesia. Yogyakarta. Lukman Offset Utama.

Wellek, Rene dan Warren Austin. t.t.Teori Kesusastraan (terjemahan melalui Budiyanto). Jakarta: Gramedia

Wiramihardja, A. Sutarjo. 2007. Pengantar Filsafat : SistematikaFilsafat, Sejarah Filsafat, Logika dan Filsafat Ilmu 'Epistemologi', Metafisika dan Filsafat Manusia, dan Aksiologi. Bandung. Aditama.

PerpresNomor 87 Tahun 2017 Tentang Penguatan Pendidikan Karakter. UU Sistem Pendidikan Nasional Republik Indonesia Tahun 2003. 